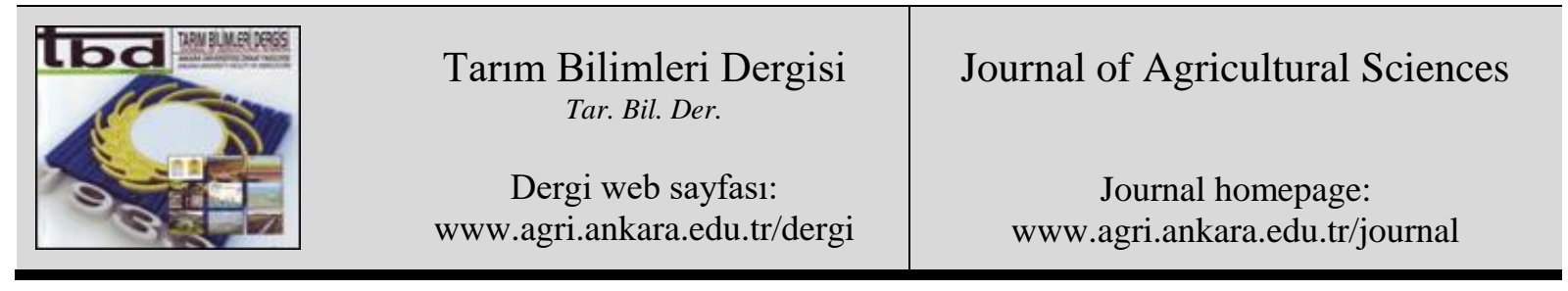

\title{
The Influence of Irrigation Water Salinity and Humic Acid on Nutrient Contents of Onion (Allium cepa $\mathrm{L}$.)
}

\author{
Ahmet TURHAN ${ }^{\text {a }}$, Bulent B. AŞIK ${ }^{\mathrm{a}}$, Hayrettin KUŞÇU ${ }^{\mathrm{c}}$

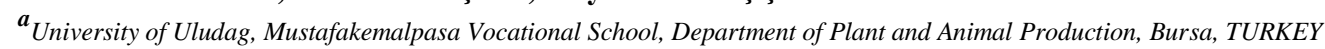 \\ ${ }^{b}$ University of Uludag, Faculty of Agriculture, Department of Soil Science and Plant Nutrition, Gorukle, Bursa, TURKEY \\ ${ }^{c}$ University of Uludag, Faculty of Agriculture, Department of Biosystems Engineering, Gorukle, Bursa, TURKEY
}

\section{ARTICLE INFO}

Research Article

Corresponding Author: Ahmet TURHAN, E-mail: turhan@uludag.edu.tr, Tel: +90 (224) 6133102

Received: 14 September 2018, Received in Revised Form: 14 January 2019, Accepted: 17 February 2019

\section{AUTHORS ORCID ID}

(Ahmet TURHAN: 0000-0002-1976-8082), (Bulent B. AŞIK: 0000-0001-8395-6283), (Hayrettin KUŞÇU: 0000-0001-9600-7685)

\section{ABSTRACT}

Humic acid (HA) efficiently enhances the uptake of nutrients of plants, especially on saline soil. In this study, some nutrient contents of onion in response to salinity and HA application were investigated, and effects of HA application on salinity resistance was evaluated. Research plots were established as a randomized factorial design with four replications on a lysimeter and each replication included 10 plants. Plants in the lysimeters were irrigated with tap water (control, EC: $0.3 \mathrm{dS} \mathrm{m}^{-}$ ${ }^{1}$ ) and four different doses of salinized water (EC: 2.0, 4.0, 6.0 and $\left.8.0 \mathrm{dS} \mathrm{m}^{-1}\right)$. The HA ( 0 and $\left.1.0 \mathrm{~g} \mathrm{~kg}^{-1}\right)$ was applied to the soil and mixed with the soil before planting. Increasing the
\end{abstract}

Keywords: Quality; Mineral nutrient; Onion; Salinity levels of irrigation salinity decreased contents of $\mathrm{K}, \mathrm{Ca}, \mathrm{N}, \mathrm{P}$, $\mathrm{Mg}, \mathrm{Fe}, \mathrm{Zn}, \mathrm{Cu}$ and $\mathrm{B}$ in onion bulbs; increased contents of $\mathrm{Na}$, $\mathrm{Cl}$ and $\mathrm{Mn}$. However, the highest content of $\mathrm{K}, \mathrm{Ca}$, and $\mathrm{N}$ in the bulbs were obtained by HA application under different salinity levels. Similarly, the soil application of HA positively was affected the $\mathrm{P}, \mathrm{Mg}, \mathrm{Fe}, \mathrm{Zn}, \mathrm{B}$ contents of the bulbs. While contents of $\mathrm{Na}, \mathrm{Mn}$, and $\mathrm{Cu}$ were not affected by soil application, $\mathrm{Cl}$ was decreased. The results showed that application of HA could partially reduce the harmful effects of salt, so HA can be used as an alternative method to improve product performance in saline conditions.

\section{Introduction}

(C) Ankara Üniversitesi Ziraat Fakültesi

Since the excess uptake of toxic ions occurs in salt impacted soils, reduce in plant growth and yield may observed in most cases (Grattan \& Grieve 1999). Ions such as $\mathrm{Na}, \mathrm{Mg}, \mathrm{Ca}, \mathrm{Cl}, \mathrm{HCO}_{3}, \mathrm{SO}_{4}$, and $\mathrm{B}$ in high quantity are responsible for soil salinity and plant growth reduction. The effect of physiological drought is one of the essential implications of salinity in plants. Soil productivity is negatively affected by a decrease in nutrient absorption of plants due to high salt concentrations in the soil (Aşık et al 2009; Khaled \& Fawy 2011).

Salinity may be originated from irrigation water (Vallejo et al 2003). Limitation in the availability of water with reasonable quality water in most arid and semi-arid places entails the saline water use for agricultural production in developing countries (Bekheet et al 2006; Kiremit \& Arslan 2016). Many researches were conducted to examine the effect of different irrigation water salinity on yield, growth and nutrient contents of numerous crops (Semiz et al 2012; Neocleous et al 2014).

Onion ranks third after potato and tomato in terms of crop production areas in the world. There are several problems in onion production, one of which, in the arid and semi-arid regions, is the effect of salinity. Hanc1 
\& Cebeci (2018) reported that onion was moderately sensitive to salinity. Initial yield decrease started at a threshold EC of $1.4 \mathrm{dS} \mathrm{m}^{-1}$, and $50 \%$ yield reduction occurred at $4.1 \mathrm{dS} \mathrm{m}^{-1}$ (Grattan \& Grieve 1999). Seed germination, seedling emergence, and seedling growth of onions were affected by soil property, the salinity of irrigation water, and irrigation method (Miyamoto et al 2010).

Humic substances are the subjects of studies in various areas of agriculture such as soil chemistry, fertility, plant physiology, and these materials can significantly improve plant growth and nutrient uptake (Paksoy et al 2010). According to Akinc1 et al (2009), HA is a product contains many elements that develop the soil fertility, increase the availability of nutrient elements by holding them on mineral surfaces, and consequently affect plant growth and yield. Khaled \& Fawy (2011) were reported that HA has positive impacts on the chemical, biological and physical properties of soils and nutrient uptake. Commercial products containing HA are mostly used in vegetable production; these products are applied to the soil along with liquid fertilizer (Hartz \& Bottoms 2010).

The agricultural area affected by soil salinization necessitates some measures such as determination of the proper salt tolerance crop types or application of some materials to diminish the effect of salinity (Lynch \& Lauchli 1988). As shown in some studies, there are positive correlations between HA and soil salinity. In this respect, Liu \& Cooper (2002) said that treatments of HA might improve the plant response to the salinity since it may increase the absorption of some nutrients and decrease the uptake of some toxic substances. Kulikova et al (2005) also declared that HA might show anti-stress effects under abiotic stress conditions. Liu \& Cooper (2002) also stated that more research should be carried out associated with HA application and its impacts on plant tolerance to salinity. Therefore, the present study was aimed to determine the effects of HA on the contents of some nutrients of onion grown under different salinity levels.

\section{Material and Methods}

\subsection{Experimental site and biological material}

The experiment was carried out in a greenhouse at the Mustafakemalpasa Vocational School (the coordinates are $40^{\circ} 02^{\prime} \mathrm{N}$, longitude $28^{\circ} 23^{\prime} \mathrm{E}$; and the altitude is $22 \mathrm{~m}$ above mean sea level), and the Department of Soil Sciences (laboratory), Uludag University, Turkey, during the spring and summer of 2013. Allium cepa L. cv. Banko was used in the experiment as the plant material. The onion seeds were obtained from the Unigen Seeds ${ }^{\circledR}$ (United Genetics Seeds Company, Inc., Mustafakemalpasa, Bursa, Turkey).

\subsection{Treatments}

This study was conducted in a completely randomized factorial design with two soil application doses of HA, (0 and $1.0 \mathrm{~g} \mathrm{~kg}^{-1}$ ) and five levels of irrigation water salinity (EC) 0.3 (control, tap water), 2.0, 4.0, 6.0 and 8.0 dS $\mathrm{m}^{-1}$. Each application consisted of four replications. There were ten plants in each lysimeter, with one lysimeter in each replicate.

\subsection{Agronomic practices}

During the first two weeks, all the treatments were irrigated with tap water. Irrigation treatments with saline water were imposed after two weeks from the planting date. Four salinity levels were prepared by adding a mixture of $\mathrm{NaCl}$ for watering the seedlings. It was necessary to maintain the quantity of the drainage water at 30 $40 \%$ of the amount of nutrient solution applied; the excess water was drained through the holes in the base of the lysimeter. Humic acid obtained from liquid Deltahumate derived from leonardite (Delta Chemicals Inc., USA) was added to the soil and mixed with the soil before planting (As1k et al 2009). Seedlings of the onion cultivar were transplanted in metallic lysimeters $(10 \mathrm{~cm}$ apart in rows of $25 \mathrm{~cm}$ in width) after 60 days from sowing in early March. Each lysimeter area was $0.26 \mathrm{~m}^{2}, 0.60 \mathrm{~m}$ depth and consisted of 10 onion plants. All of the lysimeters were randomized on benches in an unheated. Air-dried soil samples sieved through a $2 \mathrm{~mm}$ sieve and blended for homogeneity. Each lysimeter filled by $185 \mathrm{~kg}$ of soil. Some physical and chemical properties of the soil used for the experiments are presented in Table 1 . Total of $140 \mathrm{~kg} \mathrm{ha}^{-1} \mathrm{~N}$ (as ammonium sulfate) and $60 \mathrm{~kg}$ $\mathrm{ha}^{-1} \mathrm{P}_{2} \mathrm{O}_{5}$ (as superphosphate) fertilizers were applied to the soil according to recommendations based on soil analyses. The amounts of mineral fertilizers were divided into two equal portions. The first portion was applied 
during soil preparation and the second at 60 days after onion planting. The plants were grown in a greenhouse with a day/night average temperature of $21^{\circ} \mathrm{C}$ and an average relative humidity of $70 \%$.

\subsection{Harvest and analyses}

Maturity was generally observed when the crop leaves turned pale green. This was later followed by wilting and leaf fall. Whole plants were harvested in mid-July. The onion bulbs were then harvested carefully by digging them out using a hand shovel. The onion bulbs were rinsed under a tap and deionized water then sliced into pieces.

Table 1- Some physical and chemical properties of soils used in the study

\begin{tabular}{|c|c|c|c|}
\hline Property & Value & Method & Reference \\
\hline Bulk density $\left(\mathrm{g} \mathrm{cm}^{-3}\right)$ & 1.44 & Core & Rahimi et al (2011) \\
\hline Texture (sand, silt, clay \%) & $29.10-48.20-24.70$ & Hydrometer & Soil (1951) \\
\hline Organic matter $(\%)$ & 1.90 & Walkley-Black & Nelson \& Sommers (1982) \\
\hline $\mathrm{pH}$ (saturation) & 7.80 & $1: 2.5$ water extract & Richards (1954) \\
\hline $\mathrm{EC}\left(1: 2.5 \mathrm{dS} \mathrm{m}^{-1}\right)$ & 0.45 & $1: 2.5$ water extract & Richards (1954) \\
\hline Field capacity (\%) & 38.30 & Pressure plate & Obi (1974) \\
\hline Total N $(\%)$ & 0.20 & Kjeldahl & Bremmer (1965) \\
\hline Available $\mathrm{P}_{2} \mathrm{O}_{5}\left(\mathrm{mg} \mathrm{kg}^{-1}\right)$ & 12.00 & Olsen & Olsen et al (1954) \\
\hline Available $\mathrm{K}_{2} \mathrm{O}\left(\mathrm{mg} \mathrm{kg}^{-1}\right)$ & 278.00 & \multirow{3}{*}{ Flame photometer } & \multirow{3}{*}{ Pratt (1965) } \\
\hline Available $\mathrm{Ca}\left(\mathrm{mg} \mathrm{kg}^{-1}\right)$ & 4055.00 & & \\
\hline Available $\mathrm{Mg}\left(\mathrm{mg} \mathrm{kg}^{-1}\right)$ & 578.00 & & \\
\hline Available Fe $\left(\mathrm{mg} \mathrm{kg}^{-1}\right)$ & 9.00 & \multirow{4}{*}{$\begin{array}{l}\text { Atomic absorption } \\
\text { spectrophotometer }\end{array}$} & \multirow{4}{*}{ Lindsay \& Norvell (1978) } \\
\hline Available $\mathrm{Mn}\left(\mathrm{mg} \mathrm{kg}^{-1}\right)$ & 8.10 & & \\
\hline Available $\mathrm{Zn}\left(\mathrm{mg} \mathrm{kg}^{-1}\right)$ & 0.810 & & \\
\hline Available $\mathrm{Cu}\left(\mathrm{mg} \mathrm{kg}^{-1}\right)$ & 2.17 & & \\
\hline
\end{tabular}

The fresh samples were dried in a forced-air oven at $65^{\circ} \mathrm{C}$ for $48 \mathrm{~h}$. Plant total $\mathrm{N}$ (nitrogen) was detected with a Buchi K-437/K-350 digestion/distillation unit according to the Kjeldahl method (Bremmer 1965). Total elements of plant samples were digested with $\mathrm{HNO}_{3}$ and $\mathrm{H}_{2} \mathrm{O}_{2}$ (Berghof MWS 2 DAP $60 \mathrm{~K}$ microwave oven). The total cations $\mathrm{K}$ (potassium), $\mathrm{Ca}$ (calcium), $\mathrm{P}$ (phosphorus), $\mathrm{Na}$ (sodium), $\mathrm{Mg}$ (magnesium), $\mathrm{Fe}$ (iron), $\mathrm{Mn}$ (manganese), $\mathrm{Zn}$ (zinc), $\mathrm{Cu}$ (copper) and B (boron) were analyzed from extracts using the ICP OES (Perkin Elmer OPTIMA 2100 DV) (Kacar 2014). Cl (chloride) was determined by titration with silver nitrate using a potassium chromate indicator (Chapman \& Pratt 1962). The K, Ca, N, P, Na, Cl, Mg and Fe, Mn, Zn, Cu, B concentrations in the dry matter were expressed as percentages and $\mathrm{ppm}$, respectively.

The data were subjected to analyses of variance using statistical programs (IBM SPSS Statistics for Windows). Duncan is multiple range test was used to group the means of irrigation water salinity, HA, and their interactions when the F-test was significant $(\mathrm{P}<0.05)$.

\section{Results and Discussion}

Potassium (K) is a primary plant nutrient, which is needed by the plants in large amount. It is available to the plants in the form of cation $\left(\mathrm{K}^{+}\right)$. Potassium is essential for a variety of process photosynthesis, fruit formation, winter hardiness and disease resistance (Behairy et al 2015). In the present study, when the salinity increased, the $\mathrm{K}$ concentration in the onion bulbs markedly decreased under saline conditions. Our findings revealed that the interaction effect due to the combined application of salt treatments and HA application on $\mathrm{K}$ concentration in the onion bulb was significant as shown in Table 2 . When compared with the salt only, the $\mathrm{K}$ content in the onion was found to be higher in the application of HA. These results were in agreement with Rauthan \& Schnitzer (1981) who reported that the HA treatment raised the uptake of K, N, P, Fe, and Zn thereby improving the nutritional status of the plant.

Both $\mathrm{Ca}$ and $\mathrm{K}$ play a significant role in plant growth-development and control numerous processes. On the other hand, it is emphasized that increased salt concentrations negatively affect $\mathrm{Ca}$ and $\mathrm{K}$ intake by plant (Turhan et al 2013). In this study, compared with the control, no significant differences were found in the $\mathrm{Ca}$ concentration at low salinity levels $\left(2.0 \mathrm{dS} \mathrm{m}^{-1}\right)$, but increasing the salt concentration of the irrigation water above $2.0 \mathrm{dS} \mathrm{m}^{-1}$ decreased the Ca content of bulbs. However, the effect of $\mathrm{HA}$ on the Ca level in the onion bulbs, under saline irrigation water, was significant (Table 2). The Ca content in the onion bulbs was found 
higher in the HA application under the saline water irrigation. In other words, the soil applications of HA may decrease the adverse effects of the increasing salinity in onion plants, and Ca play a significant role in the life of the plants, which is essential in their growth and development. According to the literature, HA stimulates roots, increases both available plant nutrients and nutrient uptake from the soil, and improves the plants' resistance to biotic and abiotic stress factors (Cimrin \& Y1lmaz 2005).

Table 2- The effects of salinity and humic acid on some nutrient contents in onion bulb

\begin{tabular}{|c|c|c|c|c|c|c|c|c|c|c|c|c|}
\hline Treatments & $\begin{array}{l}K \\
(\%)\end{array}$ & $\begin{array}{l}\mathrm{Ca} \\
(\%)\end{array}$ & $\begin{array}{c}N \\
(\%)\end{array}$ & $\begin{array}{c}P \\
(\%)\end{array}$ & $\begin{array}{l}\mathrm{Na} \\
(\%)\end{array}$ & $\begin{array}{c}C l \\
(\%)\end{array}$ & $\begin{array}{l}M g \\
(\%)\end{array}$ & $\begin{array}{c}F e \\
\left(m g k g^{-1}\right)\end{array}$ & $\begin{array}{c}M n \\
\left(m g k g^{-1}\right)\end{array}$ & $\begin{array}{c}Z n \\
\left(m g k g^{-1}\right)\end{array}$ & $\begin{array}{c}C u \\
\left(m g k g^{-1}\right)\end{array}$ & $\begin{array}{c}B \\
\left(m g k g^{-1}\right)\end{array}$ \\
\hline $\mathrm{NaCl}_{0} \mathrm{HA}_{0}$ & $2.81 b^{(x)}$ & $1.40 \mathrm{c}$ & $2.06 \mathrm{~d}$ & 0.61 & 0.29 & $0.25 \mathrm{f}$ & 0.20 & 41.67 & $19.08 \mathrm{~cd}$ & 26.84 & 7.33 & 7.50 \\
\hline $\mathrm{NaCl}_{0} \mathrm{HA}_{1}$ & $2.91 \mathrm{a}$ & $1.90 \mathrm{a}$ & $2.47 \mathrm{~b}$ & 0.66 & 0.28 & $0.25 \mathrm{f}$ & 0.24 & 41.17 & $21.50 \mathrm{bc}$ & 27.08 & 7.75 & 8.92 \\
\hline $\mathrm{NaCl}_{2} \mathrm{HA}_{0}$ & $2.62 \mathrm{c}$ & $1.38 \mathrm{c}$ & $2.37 \mathrm{c}$ & 0.62 & 0.36 & $0.29 \mathrm{e}$ & 0.22 & 40.83 & $25.58 \mathrm{a}$ & 24.87 & 7.83 & 9.25 \\
\hline $\mathrm{NaCl}_{2} \mathrm{HA}_{1}$ & $2.76 \mathrm{~b}$ & $1.81 \mathrm{~b}$ & $2.65 \mathrm{a}$ & 0.63 & 0.35 & $0.27 \mathrm{f}$ & 0.23 & 46.33 & $22.17 \mathrm{~b}$ & 27.92 & 7.83 & 9.75 \\
\hline $\mathrm{NaCl}_{4} \mathrm{HA}_{0}$ & $2.13 \mathrm{e}$ & $1.16 \mathrm{ef}$ & $1.80 \mathrm{e}$ & 0.43 & 0.49 & $0.33 \mathrm{~d}$ & 0.19 & 33.00 & $18.67 \mathrm{~d}$ & 20.36 & 7.00 & 7.17 \\
\hline $\mathrm{NaCl}_{4} \mathrm{HA}_{1}$ & $2.48 \mathrm{~d}$ & $1.26 \mathrm{~d}$ & $1.69 \mathrm{f}$ & 0.48 & 0.49 & $0.30 \mathrm{e}$ & 0.22 & 33.67 & $23.42 \mathrm{ab}$ & 25.92 & 7.33 & 10.33 \\
\hline $\mathrm{NaCl}_{6} \mathrm{HA}_{0}$ & $1.79 \mathrm{~g}$ & $1.14 \mathrm{f}$ & $1.37 \mathrm{~g}$ & 0.34 & 0.53 & $0.50 \mathrm{~b}$ & 0.17 & 31.50 & $22.75 \mathrm{ab}$ & 14.25 & 5.58 & 5.83 \\
\hline $\mathrm{NaCl}_{6} \mathrm{HA}_{1}$ & $1.86 \mathrm{f}$ & $1.22 \mathrm{de}$ & $1.31 \mathrm{~h}$ & 0.36 & 0.51 & $0.43 \mathrm{c}$ & 0.19 & 36.58 & $22.42 \mathrm{~b}$ & 16.17 & 5.83 & 7.67 \\
\hline $\mathrm{NaCl}_{8} \mathrm{HA}_{0}$ & $1.16 \mathrm{i}$ & $0.75 \mathrm{~g}$ & $1.19 \mathrm{j}$ & 0.20 & 0.67 & $0.72 \mathrm{a}$ & 0.16 & 36.17 & $23.25 \mathrm{ab}$ & 11.48 & 5.50 & 5.58 \\
\hline $\mathrm{NaCl}_{8} \mathrm{HA}_{1}$ & $1.31 \mathrm{~h}$ & $1.12 \mathrm{f}$ & $1.26 \mathrm{i}$ & 0.25 & 0.67 & $0.73 \mathrm{a}$ & 0.18 & 31.17 & $23.75 \mathrm{ab}$ & 11.5 & 6.50 & 7.17 \\
\hline
\end{tabular}

$\mathrm{NaCl}\left(\mathrm{dS} \mathrm{m}{ }^{-1}\right)$

\begin{tabular}{|c|c|c|c|c|c|c|c|c|c|c|c|c|}
\hline 0.30 (Control) & $2.86 \mathrm{a}$ & $1.65 \mathrm{a}$ & $2.51 \mathrm{a}$ & $0.63 \mathrm{a}$ & $0.29 \mathrm{e}$ & $0.25 \mathrm{e}$ & $0.22 \mathrm{ab}$ & $41.42 \mathrm{a}$ & $20.29 \mathrm{c}$ & $26.96 \mathrm{a}$ & $7.54 \mathrm{a}$ & $8.21 \mathrm{a}$ \\
\hline 2.0 & $2.69 \mathrm{~b}$ & $1.60 \mathrm{a}$ & $2.26 \mathrm{~b}$ & $0.62 \mathrm{a}$ & $0.36 \mathrm{~d}$ & $0.28 \mathrm{~d}$ & $0.23 \mathrm{a}$ & $43.58 \mathrm{a}$ & $23.88 \mathrm{a}$ & $26.39 \mathrm{a}$ & $7.83 \mathrm{a}$ & $9.50 \mathrm{a}$ \\
\hline 4.0 & $2.30 \mathrm{c}$ & $1.21 \mathrm{~b}$ & $1.74 \mathrm{c}$ & $0.46 \mathrm{~b}$ & $0.49 \mathrm{c}$ & $0.32 \mathrm{c}$ & $0.21 \mathrm{~b}$ & $33.33 \mathrm{bc}$ & $21.04 \mathrm{bc}$ & $23.14 \mathrm{~b}$ & $7.16 \mathrm{ab}$ & $8.75 \mathrm{a}$ \\
\hline 6.0 & $1.83 \mathrm{~d}$ & $1.18 \mathrm{~b}$ & $1.34 \mathrm{~d}$ & $0.35 \mathrm{c}$ & $0.52 \mathrm{~b}$ & $0.47 \mathrm{~b}$ & $0.18 \mathrm{c}$ & $34.04 \mathrm{~b}$ & $22.58 \mathrm{ab}$ & $15.21 \mathrm{c}$ & $5.71 \mathrm{~b}$ & $6.75 \mathrm{~b}$ \\
\hline 8.0 & $1.23 \mathrm{e}$ & $0.93 \mathrm{c}$ & $1.22 \mathrm{e}$ & $0.22 \mathrm{~d}$ & $0.67 \mathrm{a}$ & $0.72 \mathrm{a}$ & $0.17 \mathrm{c}$ & $30.67 \mathrm{c}$ & $23.50 \mathrm{a}$ & $11.49 \mathrm{~d}$ & $6.00 \mathrm{~b}$ & $6.38 \mathrm{~b}$ \\
\hline
\end{tabular}

Humic acid (HA, $\left.\mathrm{g} \mathrm{kg}^{-1}\right)$

\begin{tabular}{|c|c|c|c|c|c|c|c|c|c|c|c|c|}
\hline 0.0 (Control) & $2.10 \mathrm{~b}$ & $1.17 \mathrm{~b}$ & $1.76 \mathrm{~b}$ & $0.44 \mathrm{~b}$ & 0.47 & $0.42 \mathrm{a}$ & $0.19 \mathrm{~b}$ & $35.43 \mathrm{~b}$ & 21.87 & $19.56 \mathrm{~b}$ & 6.65 & $7.07 \mathrm{~b}$ \\
\hline 1.0 & $2.26 \mathrm{a}$ & $1.46 \mathrm{a}$ & $1.87 \mathrm{a}$ & $0.47 \mathrm{a}$ & 0.46 & $0.32 \mathrm{~b}$ & $0.21 \mathrm{a}$ & $37.78 \mathrm{a}$ & 22.65 & $21.72 \mathrm{a}$ & 7.05 & $8.77 \mathrm{a}$ \\
\hline $\mathrm{NaCl}$ & $* *$ & $* *$ & $* *$ & $* *$ & $* *$ & $* *$ & $* *$ & $* *$ & $*$ & $* *$ & $*$ & $* *$ \\
\hline HA & $* *$ & $* *$ & $* *$ & $* *$ & $\mathrm{~ns}$ & $* *$ & $* *$ & $*$ & $\mathrm{~ns}$ & $*$ & $\mathrm{~ns}$ & $* *$ \\
\hline $\mathrm{NaCl} \times \mathrm{HA}$ & $* *$ & $* *$ & $* *$ & ns & ns & $* *$ & ns & ns & $*$ & ns & ns & $\mathrm{ns}$ \\
\hline
\end{tabular}

$\overline{(x)}$, small and capital letters indicate significant differences among treatments; ${ }^{*}$ and $* *$ significant at the $5 \%$ and $1 \%$ of probability level, respectively; ns, non-significant

Onion plants take up a large amount of three essential nutrients, which are the basis of growth and development, such as N, P and K (Gharib et al 2016; Akhter et al 2017). Hussein et al (2015) reported a negative correlation between salinity level and $\mathrm{N}$ concentration. In this study, salt levels significantly influenced bulb $\mathrm{N}$ content. Increasing the levels of salinity were reduced the $\mathrm{N}$ contents. However, the interaction between salinity and $\mathrm{N}$ levels was significant, application of HA positively affected the $\mathrm{N}$ content of onion bulb. (Table 2). These results are consistent with other researchers reporting that HA increased N uptake (Eyheraguibel et al 2008; AlFraihat et al 2018). On the other hand, it is emphasized that increased salt concentrations negatively affect Ca and $\mathrm{K}$ intake (Turhan et al 2013).

In the last decade, researchers have attempted to address the problem of salinity and nutrient disorder. It is well accepted that salt-stress leads P deficiency in plants by reducing P uptake (Beltrano et al 2013). In this study, $\mathrm{P}$ content was highest at control and $2.0 \mathrm{dS} \mathrm{\textrm {m } ^ { - 1 }}$ salinity levels. $\mathrm{P}$ content of the onion bulbs was significantly decreased by irrigation with saline waters having the concentrations of $4.0,6.0$ and $8.0 \mathrm{dS} \mathrm{m} \mathrm{m}^{-1}$, compared with the control (Table 2). Our findings revealed that the interaction effect between soil HA and salinity water treatments were found statistically non-significant as to K content of onion bulbs but, the soil applications of humus had a significant effect on the accumulation of $\mathrm{P}$ in onion bulbs. Although the applications of saline decreased the P content, the soil application of HA limited the decrease. P content gave the highest values by HA treatment. Mesut et al (2010) reported that HA enhances the uptake of some mineral nutrients by plants. The availability of phosphate and iron increased due to the humic application (Cimrin \& Y1lmaz 2005). 
In our study, bulb $\mathrm{Mg}$ content was significantly influenced by $\mathrm{NaCl}$ levels. The $\mathrm{Mg}$ content did not decrease significantly until a water salinity value of $2.0 \mathrm{dS} \mathrm{m}^{-1}$ was exceeded. Increasing the levels of salinity from $2.0 \mathrm{dS}$ $\mathrm{m}^{-1}$ to $4.0,6.0,8.0 \mathrm{dS} \mathrm{m} \mathrm{m}^{-1}$ significantly were reduced the $\mathrm{Mg}$ contents. On the other hand, the soil application of $\mathrm{HA}$ positively affected the $\mathrm{Mg}$ content of the onion plant, although the effect of the interaction of the $\mathrm{NaCl} \times \mathrm{HA}$ application was insignificant (Table 2). The onions treated with the application of HA rather than the untreated plants observed the higher $\mathrm{Mg}$ contents. The findings of this investigation are in close conformity with those of Asik et al (2009).

The results indicated that the $\mathrm{Fe}, \mathrm{Zn}, \mathrm{Cu}$ and $\mathrm{B}$ content of onion bulbs were strongly affected by the salt treatments; with an increased salt concentration causing a decrease in the micronutrients (Table 2). However, there were no significant differences in the $\mathrm{Fe}$ and $\mathrm{Zn}$ between the onion plants that were given the two treatments (control and $2.0 \mathrm{dS} \mathrm{m}^{-1}$ ). According to the analysis results, bulb $\mathrm{Cu}$ and $\mathrm{B}$ contents increased up to 4.0 $\mathrm{dS} \mathrm{m}^{-1}$, however increasing salt doses decreased these contents significantly. Similarly, Zhu et al (2004) reported that micronutrient deficiencies were very common under plants salt stress. Mazhar et al (2012) reported that, adding different levels of HA could alleviate the harmful effect of salinity. In another study, it was reported that humic substances in saline conditions affect plant some mineral intake and increase salt tolerance (Ouni et al 2014). These results might be because humic substances are improved nutrient uptake and ability to chelate soil nutrients (Mayhew 2004). In this connection, the soil application of HA positively affected the Fe, Zn, B contents of the onion bulb, although the effect of the interaction of the $\mathrm{NaCl} \times \mathrm{HA}$ application was insignificant (Table 2). The higher Fe, $\mathrm{Zn}$ and B contents were observed by the onions treated with the use of HA rather than the untreated plants. The results obtained are supported by previous studies, as stated by Salwa (2011) that HA essentially helps the movement of micronutrients from soil to plant. The application of HA affects the uptake of $\mathrm{Fe}, \mathrm{Zn}$, and Cu plants positively (Mayhew 2004; Eyheraguibel et al 2008; Al-Fraihat et al 2018). Grown under salt stress, $\mathrm{Mn}$ and $\mathrm{Cu}$ contents of onions were not significantly affected by supplemental HA. The research finding of Osvalde et al (2012), who indicated that the different humic substances application caused no changes in onion leaf Mn concentration, also supports this outcome.

\section{Conclusions}

In this study, the results show that different irrigation water salinity levels significantly affected the nutrient contents in onion bulb grown in a loamy soil. Increasing the levels of irrigation salinity decreased contents of $\mathrm{K}$, $\mathrm{Ca}, \mathrm{N}, \mathrm{P}, \mathrm{Mg}, \mathrm{Fe}, \mathrm{Zn}, \mathrm{Cu}$ and $\mathrm{B}$ in onion bulbs while increased contents of $\mathrm{Na}$ and $\mathrm{Cl}$. Humic acid had a significant role on increase some nutrient contents $(\mathrm{K}, \mathrm{Ca}, \mathrm{N}, \mathrm{P}, \mathrm{Mg}, \mathrm{Fe}, \mathrm{Zn}$ and $\mathrm{B}$ ) in onion grown under different salinity levels. It could be concluded that HA has a positive effect on the onion by decreasing the negative aspects of salinity stress condition. Considering the nutrient contents in the onions, the application of $1.0 \mathrm{~g} \mathrm{~kg}^{-1}$ soil humic acid can be recommended in loam soils of the arid and semi-arid regions where irrigation water is saline until $8 \mathrm{dS} \mathrm{m}^{-1}$.

\section{References}

Akhter M M, El Sabagh A, Alam M N, Hasan M K, Hafez E, Barutçular C \& Islam M S (2017). Determination of seed rate of wheat (Triticum aestivum L.) varieties with varying seed size. Scientific Journal of Crop Science 6(3): 161-167

Akıncı S, Buyukkeskin T, Eroglu A \& Erdogan B E (2009). The effect of humic acid on nutrient composition in broad bean roots. Notulae Scientia Biologicae 1(1): 81-87

Al-Fraihat A H, Al-Tabbal J A, Abu-Darwish M S, Alhrout H H \& Hasan H S (2018). Response of onion (Allium cepa) crop to foliar application of humic acid under rain-fed conditions. International Journal of Agriculture \& Biology 20: 1235-1241

Ashraf M \& Harris P J C (2004). Potential biochemical indicators of salinity tolerance in plants Plant Science 166: 3-16

Asık B B, Turan M A, Celik H \& Katkat A V (2009). Effects of humic substances on plant growth and mineral nutrients uptake of wheat (Triticum durum cv. Salihli) under conditions of salinity. Asian Journal of Crop Science 1(2): 87-95

Behairy A G, Mahmoud A R, Shafeek M R, Aisha H A \& Hafez M M (2015). Growth, yield and bulb quality of onion plants (Allium cepa L.) as affected by foliar and soil application of potassium. Middle East Journal of Agriculture Research 4(1): 60-66

Bekheet S A, Taha H S \& Solliman M E (2006). Salt tolerance in tissue culture of onion (Allium cepa L.). Arab Journal of Biotechnology 9(3): 467-476 
Beltrano J, Ruscitti M, Arango M C \& Ronco M (2013). Effects of arbuscular mycorrhiza inoculation on plant growth, biological and physiological parameters and mineral nutrition in pepper grown under different salinity and $\mathrm{P}$ levels. Journal of Soil Science and Plant Nutrition 13(1): 123-141

Bremmer J M (1965). Total nitrogen. In: Black CA (Ed), Methods of soil analysis, part 2 chemical and biological methods. American Society of Agronomy Publication, Agronomy Series, No.9, Madison Wisconsin USA pp. 1149-1178

Chapman H D \& Pratt P F (1962). Methods of analysis for soils plants and waters. Soil Science 93(1): 68

Cimrin K M \&Y1lmaz I (2005). Humic acid applications to lettuce do not improve yield but do improve phosphorus availability. Acta Agriculturae Scandinavica, Section B, Soil and Plant Science 55: 58-63

Eyheraguibel B, Silvestre J \& Morard P (2008). Effects of humic substances derived from organic waste enhancement on the growth and mineral nutrition of maize. Bioresource Technology 99: 4206-4212

Gharib H, Hafez E \& El-Sabagh A (2016). Optimized potential of utilization efficiency and productivity in wheat by integrated chemical nitrogen fertilization and simulative compounds. Cercetari Agronomice in Moldova 2(166): 5-20

Grattan S R \& Grieve C M (1999). Salinity-mineral nutrient relations in horticultural crops. Scientia Horticulture 78: 127-157

Hanc1 F \& Cebeci E (2018). Improvement of abiotic stress tolerance in onion: selection studies under salinity conditions. The International Journal of Engineering and Science 7(9): 54-58

Hartz T K \& Bottoms T G (2010). Humic substances generally ineffective in improving vegetable crop nutrient uptake or productivity. HortScience 45(6): 906-910

Hussein M M, El-Dewiny C Y \& El-Faham S Y (2015). Mineral content response in onion to antioxidant application under salt stress conditions. International Journal of ChemTech Research 8(12): 20-27

Kacar B (2014). Plant, soil and fertilizer analysis. II.Nobel Academic Publisher 407 pp. Ankara, Turkey

Khaled H \& Fawy H A (2011). Effect of different levels of humic acids on the nutrient content, plant growth, and soil properties under conditions of salinity. Soil and Water Research 6(1): 21-29

Kiremit M S \& Arslan H (2016). Effects of irrigation water salinity on drainage water salinity, evapotranspiration and other leek (Allium porrum L.) plant parameters. Scientia Horticulturae 201: 211-217

Kulikova N A, Stepanova E V \& Koroleva O V (2005). Mitigating activity of humic substances: direct influence on biota. In: Perminova I, Hatfield K, Hertkorn N (Eds). Use of humic substances to remediate polluted environments: from theory to practice. Netherlands Springer pp. 285-309

Lindsay W L \& Norvell W A (1978). Development of a DTPA soil test for zinc, iron, manganese and copper. The Soil Science Society of America Journal 42: 421-428

Liu C \& Cooper R J (2002). Humic acid application does not improve salt tolerance of hydroponically grown creeping bentgrass. Journal of the American Society for Horticultural Science 127(2): 219-223

Lynch L \& Lauchli A (1988). Salinity affects intracellular calcium in corn root protoplasts. Plant Physiology 87: 351-356

Mayhew L (2004). Humic substances in biological agriculture. ACRES USA. A voice for Eco-Agriculture 34(1-2): 8

Mazhar A A M, Shedeed S I, Abdel-Aziz N G \& Mahgoub M H (2012). Growth, flowering and chemical constituents of Chrysanthemum indicum L. Plant in response to different levels of humic acid and salinity. Journal of Applied Science Research 8(7): 3697-3706

Mesut C K, Onder T, Metin T \& Burcu T (2010). Phosphorus and humic acid application alleviate salinity stress of pepper seedling. African Journal of Biotechnology 9(36): 5845-5851

Miyamoto S, Niu G \& Martinez I (2010). Salinity and specific ion effects on onion establishment in relation to disposal of desalting concentrates. Desalination and Water Treatment 16: 381-392 
Nelson D W \& Sommers L (1982). Total carbon, organic carbon and organic matter. Methods of Soil Analysis, Part 2. Chemical and microbiological properties. Agronomy Monograph No: 9 ( $2^{\text {nd }}$ Ed.). ASA-SSSA, Madison, Wisconsin, USA pp. 539-579

Neocleous D, Koukounaras A, Siomos A S \& Vasilakakis M (2014). Assessing the salinity effects on mineral composition and nutritional quality of green and red "baby" lettuce. Journal of Food Quality 37: 1-8

Obi M A (1974). The wilting point and available moisture of tropical forest soils in Nigeria. Experimental Agriculture 10: 305-312

Olsen S R, Cole C U, Watanabe F S \& Dean H C (1954). Estimation of available phosphorus in soils by extraction with sodium bicarbonate. U.S. Department of Agric. Circ., pp. 939

Osvalde A, Karlsons A, Èekstere G \& Maïecka S (2012). Effect of humic substances on nutrient status and yield of onion (Allium cepa L.) in field conditions. Proceedings of the Latvian Academy of Sciences Section B 66: 192-199

Ouni Y, Ghnaya T, Montemurro F, Abdelly C \& Lakhdar A (2014). The role of humic substances in mitigating the harmful effects of soil salinity and improve plant productivity. International Journal of Agronomy and Plant Production 3(8): 353-374

Paksoy M, Turkmen O \& Dursun A (2010). Effects of potassium and humic acid on emergence, growth and nutrient contents of okra seedling under saline soil conditions. African Journal of Biotechnology 9(33): 5343-5346

Pratt P F (1965). Methods of Soil Analysis. Part 2. Chemical and microbiological properties. Ed. C.A. Black. American Society Agronomy Inc. Publisher Agro. Series No 9, Madison, USA

Rahimi A A, Sepaskhah A R \& Ahmadi S H (2011). Evaluation of different methods for the prediction of saturated hydraulic conductivity in tilled and untilled soils. Archives of Agronomy and Soil Science 57(8): 899-914

Rauthan B S \& Schnitzer M (1981). Effect of fulvic acid on the growth and nutrient content of cucumber (Cucumis sativus L.) plants. Plant and Soil 63: 491-495

Richards L A (1954). Diagnosis and improvement of saline and alkali soils. United State Department of Agriculture, Agriculture Handbook No: 60

Salwa A I E (2011). Effect of amendments, humic and amino acids on increases soils fertility, yields and seeds quality of peanut and sesame on sandy soils. Research Journal of Agriculture and Biological Sciences 7(1): 115-125

Semiz G D, Ünlükara A, Yurtseven A, Suarez D L \& Telci I (2012). Salinity impact on yield, water use, mineral and essential oil content of fennel (Foeniculum vulgare Mill.). Journal of Agricultural Science 18: 177-186

Soil Survey Manual (1951). U.S. Dept. of Agriculture. Soil Conservation Service. Soil Survey Staff. U.S. Dept. Agriculture, Handbook No: 18. U.S. Govt. Print. Off. Washington, DC. 503, Illus

Tavakkoli E, Rengasamy P \& McDonald G K (2010). High concentrations of $\mathrm{Na}$ and $\mathrm{Cl}$ ions in soil solution have simultaneous detrimental effects on growth of faba bean under salinity stress. Journal of Experimental Botany 61: 44494459

Turhan A, Kuşçu H, Özmen N, Aşık B B, Şerbeci M S \& Şeniz V (2013). Alleviation of deleterious effects of salt stress by applications of supplementary potassium-calcium on spinach. Acta Agriculturae Scandinavica Section B-Soil and Plant Science 63: 184-192

Vallejo F, Tomas-Barberan F A \& Garcia-Viguera C (2003). Effect of climatic and sulphur fertilisation conditions on phenolic compounds and vitamin $\mathrm{C}$, in the inflorescence of eight broccoli cultivars. European Food Research and Technology 216(5): 395-401

Zhu Z, Wei G, Li J, Qian Q \& Yu J (2004). Silicon alleviates salt stress and increases antioxidant enzymes activity in leaves of salt-stressed cucumber (Cucumis sativus L.). Plant Science 167: 527-533 